\title{
SLCO2B1 wt Allele
}

National Cancer Institute

\section{Source}

National Cancer Institute. SLCO2B1 wt Allele. NCI Thesaurus. Code C105430.

Human SLCO2B1 wild-type allele is located in the vicinity of 11q13 and is approximately $106 \mathrm{~kb}$ in length. This allele, which encodes solute carrier organic anion transporter family member 2B1, plays a role in transport of organic anions and may function in regulation of placental uptake of sulfated steroids. 